
\title{
Reseacch S Suare \\ Propidium monoazide sequencing has limited utility in microbial community viability assays
}

\author{
Ya Wang \\ Yan Yan \\ Kelsey N. Thompson \\ Sena Bae \\ Emma K. Accorsi \\ Yancong Zhang \\ Jiaxian Shen \\ Hera Vlamakis \\ Erica M. Hartmann \\ Curtis Huttenhower
}

\section{Video Byte}

Keywords: Microbiome, Propidium monoazide, 16S rRNA-sequencing, built environment communities, PMA, viability, culture-independent, microbial community characterization

Posted Date: February 25th, 2021

DOI: https://doi.org/10.21203/rs.3.rs-276085/v1

License: (c) (i) This work is licensed under a Creative Commons Attribution 4.0 International License. Read Full License 


\section{Abstract}

Complex microbial communities can be characterized with many different techniques. Because culturing bacteria can be time-consuming, many culture-independent methods have been developed. However, unlike culture-based techniques, many of these methods cannot differentiate metabolically active from non-viable community members. Some studies have used propidium monoazide (PMA) to assess viability, but the technique itself has yet to be systematically assessed. A new study sought to fill this gap for "PMA-seq" using both synthetic and realistic bacterial communities. They found that PMA-seq successfully reconstructed the structure of the synthetic communities. but it could not accurately quantify viability in the realistic communities. The results were affected by the initial biomass, sample type, and compositional diversity of the original sample. Further analysis showed that "PMA responsiveness" varied with the ecosystem the microbes originated from, but remained consistent within similar environments across studies. Overall, these results suggest that PMA-seq is useful for semiquantitative analysis in simple synthetic communities. But might be limited to qualitative analysis for more complex, real-world bacterial communities. 